\title{
THE MAINTENANCE OF CAKAP KARO IN KELURAHAN SEMPAKATA MEDAN
}

\author{
Ingrid Gibretta Khairani Ginting \\ IAKN TARUTUNG \\ Ingridgibretta11@gmail.com
}

Submit, 16-06-2020 Accepted, 26-06-2020 Publish, 27-06-2020

\begin{abstract}
This research aims at describing the maintenance of Cakap Karo in Kelurahan Sempakata Medan which was focus on Karonese parents' attitude toward heritage language maintenance for their children and their efforts to help their children maintain Cakap Karo as their heritage language in Kelurahan Sempakata Medan. This research is conducted by using qualitative method. Data were collected from twenty Karonese parents who had a child (or children) between the ages of 6-18 years old in 2019, using the questionnaire and interviews. The result revealed that all the parents in this study had positive attitudes and efforts toward their children's heritage language maintenance. There are some parents' effort to enhance children's Cakap Karo skill that found in this research; communication use Cakap Karo at home, use Karonese books, educational Karonese vocabulary books and Karonese songs, bring to the church of GBKP (Gereja Batak Karo Protestan) and traditional ceremonies, and connect with Karonese relatives and friends in home town using internet. This study confirms that parents' attitude and efforts play important role in language maintenance.
\end{abstract}

Keywords: Maintenance, Cakap Karo, Parents' attitude, Heritage Language, Kelurahan Sempakata

\section{INTRODUCTION}

The Republic of Indonesia is a very large nation with correspondingly large population and great linguistic diversity. The nation extend over almost 3,000 kilometers: from Banda Aceh at the western tip of Sumatera to Kupang in West Papua is approximately: 2,830 kilometers. Estimates vary, but the nation includes somewhere in the region of 17,000 islands of which 6,000 are inhabited. Ethnologue 15 lists Indonesia as having 742 languages spoken within its borders, although others sources suggest that the methodology adopted in this publication results in a figure which is too high (Steinhauer, 1994). On the basis of their figure, Ethnologue makes Indonesia the 26th most linguistically diverse nation in the world. The Republic of Indonesia has its national language, Bahasa Indonesia (Indonesian language); which is standardized Malay variety. The period since the 
founding of the Indonesian nation, since 1945, has coincided with great changes in communication and technology, and it is not suprising that knowledge and the use of the national language has increased over this period.

Every human being needs language to communicate each other. They use language in their daily communication. They can express everything in their mind by using language to follow every human's activities. In other words, without language they cannot communicate each other and they will get difficulty in it, because language is important part of human being to express their ideas. And it applies to Karo people, they use language to communicate each other, which is Cakap Karo (Karo Language). Cakap Karo is important part of Karonese because they can express everything in their mind using Cakap Karo. Karonese is one of the sort ethnics of Bataknese in North Sumatera, Indonesia.

Using Cakap Karo in their daily communication, it is shown the identity of Karonese. Cakap Karo is a symbol identity of the Karonese. Ethnic identity is the way in which the expression through a particular language. Attachment to language is as strong as people regard themselves as social group, which is influenced largely by how the larger society regards them.

Some parents urge the children to shift to Bahasa Indonesia as quickly as possible in order to assimilate and succeed in the main stream society, whereas other parents would like to take on the challenge of maintaining the home language in the next generation. These different language ideologies directly impact the second generation children's language maintenance. Although literature on language maintenance and language shift has been extensive, most of this studies focus on Karonese children in Kelurahan Sempakata Medan.

This study confirms others' finding that parents' attitude and efforts play important role in language maintenance. Some of the relevant research that has been done before by the researcher regarding language maintenance are: Zuri, (2018). this research found the following results (1) there are seven factors affecting Mandailing Language maintenance such as: use of language in family, visiting homeland, use of the language in neighborhood domain, ethno linguistic vitality, living together in an area, use of the language in religion and practice of traditional ceremony; (2) to maintain Mandailing Language, the Mandailing people conducted strategies like: Family language policy, using Mandailing language in daily life, using Mandailing language in social meeting or religious, using Mandailing language in cultural activity; (3) the reasons why the Mandailing people maintain the language are: they were proud being Mandailing people and speak Mandailing language and Mandailing language shows their identity as Mandailing people.

Harahap, (2018) this research found the following results (1) there are four types of language maintenance of Mandailingnese language, they are low 
maintenance, medium maintenance, strong maintenance and extreme maintenance; (2) there are two ways found to maintain the language, they are join the community, teach the language to younger sister/brother; (3) there are two reasons why they maintain their language, they are to tell certain issue and to creat closer relationship.

Okpanachi \& Joseph, (2017) the findings show that each respondent is proficient in his or her native language and inn the dominant language, Igala. Factors relations such as marriage, economic, communal and other socio-cultural activities. Another factor is religion. This work show that the three language used in the community have co-existed without any of them being endangered. Savitri, (2019) this research describes Javanese language maintenance through printed mass media, particularly comic strip on newspaper, tabloid and magazine. The writer shows how a comic strips in printed mass medai indirectly preserve spoken Javanese.it making the speakers proud of using the langauge and making the language is used in daily and modren usage.

Farisiyah \& Zamzani, (2018) the findings from this study demonstrates that local languages have not been shifted yet because they are still frequently used in the family and neighborhood area. In other words, local languages are not shifted, yet maintained though in educational and general places are in the contrary. Dewi, (2017) the first finding shows that there were six factors affecting language shift and language maintenance occured in intermarriage chinese families namely bilingualism, migration, economic, environment, demographic and attitude. And the second finding was that language shift and language maintenance occured since there are two languages exist in inter ethnic marriage. The third finding was the reasons language shift and language maintenance occured are bilingualism in which the man or the woman mastered two languages which led to language maintenance, migration in which the women migrate to follow their husband, economic factor dealing with the men and women's occupation, environment where they lived in homogenous or heterogeneous ethnic, demographic factor, and attitude which might be positive or negative.

Suryasa \& Dewi, (2018) from the research conducted, it could be known that Balinese language agricultural field at Desa Canggu, North Kuta Subdistrict, Badung Regency have a positive language attitude, that is to keep using the traditional agricultural vocabulary from the original Balinese language adttion to the new vocabulary from other languages. Liang, (2018) the findings suggest that parental perceptions may change due to practical considerations and vary with different degrees of expectation, emphases, and reasons. The body literature shows that parents take the responsibility to make efforts, through trying to make full use of the inhouse and external resources such as creating language environment and attending heritage language school and church. Some of them 
have little enthuasiasm, and some of them change their language practices. It is concluded that joint efforts from parents, educational institutions, governments, and their organizations should be made to tackle the issue in heritage language maintenance.

Matrejo, (2017) the result of the study were found that there were six factors of Javanese language maintaining the language namely seeing each other frequently (100\%), neighborhood domain (97\%). Ethno linguistic vitality (100\%), family domain (99\%), religion domain (55\%) and practice the traditional ceremony (35\%). Then the way of maintaining the Javanese language were found namely acquisition of the language (40\%), create a socially integrated population of native speakers $(60 \%)$, localities of habitually using the language $(80 \%)$ and the last was speak language in area oral competence $(35 \%)$. The reasons of Javanese Intermarriages maintained the language namely show identity (90\%), pride $(100 \%)$ and keep the language $(100 \%)$.

Amna (2018) this study focuses specifically on investigating the maintenance of Bahasa Aceh by Acehnese teenagers in Keude Kopi in Medan. It has been found that there were some factors lead to the maintenance of Bahasa Aceh, they are language attitude, parents' role, environment, visiting homeland continously and intra-marriage. The maintenance of Bahasa Aceh was done by keep using it to other Acehnese, read the Acehnese online or printed media, and watch or listen to the Acehnese entertainment. In maintaining their mother language, the teenagers' reason were not only about showing their identity, help their community to progress and achieving self-esteem and/or self-pride, but also to create the feel-like-home station, since using the language with the same Acehnese peers makes them feel closer and bound.

This research had different findings with the previous studies and supportive by previous theories. The present study intends to close this gap by providing more in-depth knowledge of families' experiences with home language maintenance among second-generation Karonese children. In this study, I explore Karonese parents' attitude toward heritage language maintenance for their children and their efforts to help their children maintain Cakap Karo as their heritage language in Kelurahan Sempakata Medan. I have some reasons for choosing this topic. First, Karonese children in Kelurahan Sempakata Medan are seldom of using Cakap Karo as their daily language. The second, I want to know the attitude and efforts of Karonese parents' to help their children maintain Cakap Karo as their heritage language in Kelurahan Sempakata Medan.

\section{LITERATURE REVIEW}

Language must be maintained because language showed the identity of the language users. As (Holmes, 1993) stated that where language is considered as 
important symbol of a minority group's identity, the language is likely to be maintained longer. Moreover (Corson, 2001) said that the maintenance of a heritage language is a vital for the self-identity and esteem of its speakers. Therefore, language must be protected, preserved, and maintained.

Mesthrie, (1999) defines language maintenance as "the continuing use of a language in the face of competition from a regionally and socially powerful or numerically stronger language". It is usually presented as the reverse side of language shift: that is, change from habitual use of one's minority language to that of a more dominant language under pressures of assimilation from the dominant group (Fishman, 1974). Overall, past research has consistently shown that language language shift is much more common phenomenon among immigrant children than language maintenance. (Fishman, 1974) describes the structure of linguistic shift as a three-generation process. In the Indonesia context, the first generation learns as much as Bahasa Indonesia as it can but speaks the mother tongue at home. The second generation may speak the mother tongue at home but shifts to unaccented Bahasa Indonesia at school and in the workplace. By the third generation, Bahasa Indonesia becomes the home language and effective knowledge of the parental tongue dissapears.

It is clear that there is a role for family to play in children's first language maintenance. (Liang, 2018) examined parental perceptions toward and practices of heritage language maintenanc in the United States and Canada. This study shows that most of the immigrant parents in North America share positive attitude toward their children's heritage language learning and maintenance, at least before their children entering into the formal schooling system. The results of this study also reveal that all participants lay most of the responsibility on parents for children's first language maintenance. In this study, we examined Karonese parents' attitudes toward heritage language maintenance for their children and their efforts to help their children maintain Cakap Karo as their heritage language in Kelurahan Sempakata Medan context where there is a majority language, Bahasa.

In particular, Karonese parents' attitude toward the Karonese ethnic churches (GBKP) as one of the most important ethnic communities in Kelurahan Sempakata Medan were also investigated for relevance to their children's heritage language and culture maintenance. Regarding the role of community in minority students' first language maintenance, (Pak, 2003) describes the Korean church as one of the important communities in which Korean-American students can learn their culture and heritage language. She found that Korean churches served as a bilingual and bicultural context for Korean-American children. Interviews with the adults in the church also show that Korean language maintenance is closely connected with Korean identity maintenance. 


\section{RESEARCH METHOD}

Twenty Karonese parents (ten fathers and ten mothers) who has a child (or children) between the ages of 16-18 were included in this project. The ages of participants were between the ages of 32 and 50. They were all born in Medan. All the participants identified Karonese as their heritage language. Participants provided bio-data and participated interviews. Participants were recruited through Karonese church (GBKP), the scholl, and the author's personal contacts.

The questionnaire on bio-data contained 12 items about participants' personal background, status, and proficiency levels in Bahasa and Cakap Karo. After participants completed the questionnaire at the beginning of the study, they were asked to participate in an interview with the author. The interview was divide into two parts. The first section contained nine items about Karonese parents' attitudes toward heritage language and cultural identity maintenance for the children and attitudes toward the Karonese language, the Karonese community and Karonese churches in Kelurahan Sempakata Medan. The second section contained four items about Karonese parents' efforts to help their children maintain the heritage language both at home and outside the home. The interviews were audio-recorded in Karonese and conducted wherever the participants felt comfortable. Main points were transcribed and translated into English by the author.

\section{FINDINGS}

The results indicated that all the participants wanted their children to maintain the Cakap Karo. Parents' attitudes towards the heritage language and their efforts to enhance their children's heritage language skills will be discussed in the following pages.

\section{Parents' Attitudes Toward The Heritage Language}

The result revealed that all the parents in this study had positive attitudes toward their children's heritage language maintenance. With regard to the reasons for wanting children to maintain the heritage language, all the participants responded their children should maintain the heritage language in order to keep their identity as Karonese. This result shows that Karonese parents strongly support their children's heritage language maintenance to enable them to keep their cultural identity through Cakap Karo. This result can be supported by the relationship between the heritage language and identity. As (Cavallaro, 2005) mentions, language is one of the most important factors for ethnic identity in multilingual situations. In addition, heritage language development may help immigrant children define their cultural identity more positively in multicultural and multilingual societies, since being bilingual may promote their acceptance of 
both the majority culture and their heritage culture. Karonese parents believed that the maintenance of the heritage language can facilitate their children's positive identity formation.

With regard to another reason why Karonese children should maintain the heritage language, one parent mention the importance of first language skills in children's academic success and second language learning. She stated that her children started to learn Cakap Karo as their first language in Medan, so they had to keep developing their first language, since effective second language learning and academic success would be possible based on the firm foundation of the first language skills. This result is in accord with (Cummins, 1989) linguistic interdependence principle, which suggests that 'there is an underlying cognitive and academic proficiency which is common across languages'. Cummins claims that a strong foundation in minority students' first language enhances their second language learning and second language academic skills. He insists that linguistic minority students' effective and fast acquisition of second language literacy skills and academic skills can be greatly facilitated and enhanced by their first language conceptual knowledge.

\section{Parents' Efforts To Enhance Children's Cakap Karo Skills}

Most parents thought that parents should help their children maintain their Cakap Karo in this study. All the participants responded that they tried to communicate with their children at home. This result shows that Karonese parents use Cakap Karo with their children at home. Even though children's Cakap Karo skills are not strong enough to communicate with parents solely, parents respond that they try to use as much Cakap Karo as is practical in order to keep their children's receptive competence as high as possible. They strongly believe that the use of Cakap Karo at home is the most important factor to their children's heritage language maintenance.

Also, sixteen parents responded that they use Karonese books to help children maintain their Cakap Karo. They made their children read Karonese books by themselves or they tried to read the Karonese books together with their children. In addition, some (two out of twenty) parents used educational Karonese vocabulary books in order to teach their children the Cakap Karo systematically. Others parents also mentioned the use of Karonese songs to study their heritage language. For the Christianity family, they bring their children to the church of GBKP (Gereja Batak Karo Protestan). In this church, all people using Cakap Karo during worship. So, from this worship their children can enhance their Cakap Karo skill. Some parents also bring their children to the traditional ceremonies to help their children maintain Cakap Karo at home and outside home. 
As we mentioned before, since there is no systematic support from the community, most parents interviewed (seventeen) rely on church activities to provide a Karonese-speaking outside the home. In addition, all participants responded that they encouraged their children to connect with Karonese relatives and grandparents using the Internet and the smartphone. Most of the children in this study had contact with their Karonese relatives, grandparents and friends more than once a week in order to keep their links to their family in hometown.

\section{DISCUSSION}

It is important to note that the findings reported here may not be generalisable to all Karonese people in Kelurahan Sempakata Medan, since only 20 parents participated. People in Kelurahan Sempakata Medan is heterogeneous society. The population consists of various culture such as Karonese, Javanese, Tobanese, Mandailingnese, Simalungunese, etc. So, when they comunicate with other ethnic comunities, they use Bahasa. It has caused a language shift in their heritage language. The circumstances like this make Sempakata's people become a multilingual society. This society tend to take a stand in using their heritage language in communication. The attitude of the community as a effort to use their heritage language is called language maintenance.

If related to the theory put forward by ( $\mathrm{Li}, 1999)$, parents' positive attitudes towards their children's heritage language and culture are benefit for the maintenance of their identity and heritage language as well as for the development of their second language. Li also mentions that supportive interaction between parents and children at home using their heritage language plays an important role in helping immigrant children maintain their heritage language. If a situation where parents tries to use their language to maintain their heritage language, then the attitude of Sempakata's parents leads to language maintenance because all the parents had positive attitudes toward their children's heritage language maintenance.

Language maintenance has been an issue debated whenever languages come into contcact. (Harahap, 2018) describes there were two strategies that conducted by Mandailingnese people in Tanjungbalai to maintain Mandailingnese language. They are join the community and teach the language to younger sister/brother. In this study, Karonese parents help their children maintain their Cakap Karo through communicate using Cakap Karo with their children at home. Karonese parents use Karonese books to help their children maintain their Cakap Karo. They made their children read Karonese books by themselves or they tried to read it together at home. In addition, some parents used Karonese songs in order to teach their children by sing the song at home or in the traditional events. 
Based on the result of the attitude of Cakap Karo's maintenance in Kelurahan Sempakata Medan, the society can maintain their heritage language even though some have experienced language shift. Furthermore, the maintenance of Cakap Karo is also the maintenance of culture because every culture activity needs to use a language. For this case, Cakap Karo is an element national culture for Indonesia should be perserved.

\section{CONCLUSION}

Based on the results and discussion of the research can conclude that Karonese parents in Kelurahan Selayang Medan are very positive toward their children's heritage language maintainance. In addition, Karonese parents' expectations for their children's proficiency level in the Cakap Karo are very high. They believe that their children's high level of proficiency in the Cakap Karo would help their children keep their cultural identity as Karonese, ensure them better future economic opportunities, and give them more chances to communicate with their extended families and grandparents efficiently. It shows that Karonese parents are very dedicated to their children's heritage language education at Kelurahan Selayang Medan. They strongly believe that parents are mainly responsible for their children's heritage language and culture maintenance. Parents' positive attitudes toward their children's heritage language maintenance will help their children develop and enhance the Cakap Karo skills in a multilingual context.

\section{REFERENCES}

Amna, E. (2018). Maintaining Bahasa Aceh in Keude Kupi Among Teenagers in Medan. Jurnal Linguistik Terapan Pascasarjana, 15(1), 8-14.

Cavallaro, F. (2005). Language Maintenance Revisited: An Australian Perspective Linguistic Diversity in Australia. Bilingual Research Journal, 29(3), 561-582.

Corson, D. (2001). Language Diversity and Education. University of Minnesota.

Cummins, J. (1989). Empowering Minority Students.: California (Print book). Sacramento, CA (926 J St., Suite 810, Sacramento 95814): California Association for Bilingual Education, 1989.

Dewi, M. (2017). Language Shift and Maintenance of Intermarriages Chinese Families. Jurnal Linguistik Terapan Pascasarjana, 14(2), 110-121.

Farisiyah, U., \& Zamzani. (2018). Language Shift and Language Maintenance of Local Languages toward Indonesian. Social Science, Education and Humanities Research, 165(Iccsr), 231-235.

Fishman, J. (1974). Advances in Language Planning (J. Fishman (ed.)). The Hague.

Harahap, N., H. (2018). The Maintenance of Mandailingnese Language in Tanjungbalai. Jurnal Linguistik Terapan Pascasarjana, 15(2), 157-164.

Holmes, J. (1993). An Introduction to Sociolinguistics. In An Introduction to 
Sociolinguistics (Fourth edi, Vol. 77, Issue 3). Routledge. https://doi.org/10.2307/329116

Li, X. (1999). How Can Language Minority Parents Help Their Children Become Bilingual In Familial Context? A Case Study Of A Language Minority Mother And Her Daughter. Bilingual Research Journal, 23 (2 dan 3), 113125.

Liang, F. (2018). Parental Perceptions Toward and Practices of Heritage Language Maintenance: Focusing on The United States and Canada. International Journal of Language Studies, 12(2), 65-86.

Matrejo. (2017). Language Maintenance of The Javanese Intermarriages in Rantau Utara. Jurnal Linguistik Terapan Pascasarjana, 14(3), 253-264.

Mesthrie, R. (1999). Fifty Ways to say 'I do': Tracing the Origins of Unstressed do in Cape Flats English, South Africa. South African Journal of Linguistics, 17(1), 58-71.

Okpanachi, D., A., \& Joseph, A. (2017). Language Use and Language Maintenance in Olowa, Dekina Local Government Area, Kogi State, Nigeria. International Journal of English Language and Linguistic Research, 5(6), 13-27.

Pak, H. (2003). When MT is L2: The Korean Church School as a Context for Cultural Identity (P. N. H. Hornberger (ed.); ontinua of). Multilingual Matters.

Savitri, A., I. (2019). Language Maintenance Through Comic Strips. Culturalistics: Journal of Cultural, Literary, and Linguistic Studies, 3(1), 11-16.

Steinhauer, H. (1994). The Indonesian Language Situation And Linguistics; Prospects And Possibilities. Bijdragen Tot de Taal-, Land- En Volkenkunde, 150(1), 755-784.

Suryasa, I., W., \& Dewi, A., A., S. C. (2018). Language Maintenance of Balinese Vocabulary in Agriculture : Eco Linguistic Studies. International Journal of Linguistics, Literature and Culture, 4(4), 38-43. https://doi.org/10.21744/ijllc.v4n4.258

Zuri, N. (2018). Mandailing Language Maintenance in Kelurahan Sudirejo II Medan. Jurnal Linguistik Terapan Pascasarjana. 2(3), 22-33 